\title{
Med humor som våben - sproglig humor som bindeled mellem kognition og emotion
}

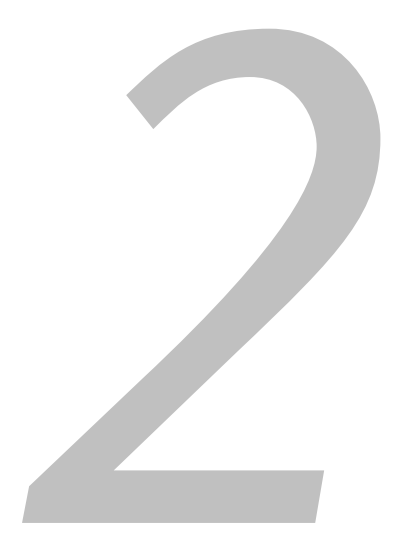

\author{
THOMAS RAAB \\ Uafhængig forsker, København, Danmark
}

\begin{abstract}
The attempt to establish a coherence between the cognitive description of language and thought and the neurobiological description of the human brain is often limited by lacking knowledge concerning the interplay between cognition and emotion - both necessary elements in understanding the way the brain works. Verbal humor is a convenient research object in this regard, as it consists (primarily) in cognitive mechanisms, eliciting an emotional response - laughter. In this article, a review of the history of humor research is compared to a selection of studies (lesion-studies, ERP and $\mathrm{fMRI}$ ) on the relationship between humor, language and the brain, as an attempt to show how a broadly based theory of humor can help us to understand the relationship between cognition and emotion.
\end{abstract}

\section{INDLEDNING}

\author{
Den, som kun ta'r spøg for spøg \\ og alvor kun alvorligt, \\ han og hun har faktisk fattet \\ begge dele dårligt. \\ - Piet Hein
}

Ovenstående er vel nok det mest berømte danske citat om humor. Forklaringen herpå er uden tvivl, at det gengiver en intuitiv erkendelse af, at spøg, sjov og humor faktisk kan lære os noget - også om emner, som vi er vant til at betragte med en helt anden alvor. Denne erkendelse står på flere fronter i opposition til den videnskabelige tradition, som i stedet ofte har gjort en dyd ud af at "holde skæg for sig og snot for sig" - ikke kun i den forstand, at videnskabelige bestræbelser på at forstå humoren og dens væsen langt fra altid har været lige 
velsete (Svebak 2000), men også i kraft af opdelingen af videnskaben i særskilte discipliner med hver sit begrebsapparat, metode og tradition.

Den stigende interesse, vi i disse år oplever i at koble beskrivelsen af f.eks. vores sprogforståelse med undersøgelser af hjernens funktioner - som også dette bind, hvis emne er forskellige aspekter af forsøget på at skabe en egentlig neurolingvistik, er et udtryk for - stiller imidlertid stadig større krav om en tværfaglig forståelse af de fænomener, som undersøges. Da hjernen primært er et biologisk organ, hvis vigtigste opgave er at kombinere alle tilgængelige, brugbare informationer $\mathrm{i}$ en samlet bestræbelse på at vælge den biologisk set mest fordelagtige adfærd, er en samlet forståelse af de forskellige elementers rolle i denne proces påkrævet for at kunne forstå og fortolke de resultater, som de stadigt mere detaljerede undersøgelser af hjernens aktivitet fremkommer med. Dette gælder ikke mindst samspillet mellem de to væsentligste elementer i hjernens skabelse af den menneskelige virkelighedsopfattelse (Damasio 1994, 1999, 2003) - kognition og emotion.

Som forskningsobjekt giver sproglig humor i denne sammenhæng en enestående mulighed for at belyse samspillet mellem kognition og emotion, idet den sproglige - og særligt den skriftsproglige - humor i sin grundform består af (primært) kognitive mekanismer, som udløser en emotionel respons ${ }^{1}$.

\section{HUMOR FØR OG NU}

Det er muligt, at man bør kalde en spade for en spade. Men i humor er ting aldrig, hvad de giver sig ud for at være - og dette gælder også for humoren selv. Før vi kaster os ud i den i bund og grund halsløse gerning, det er at forsøge at levere en fyldestgørende beskrivelse af humorens mekanismer, må vi derfor skabe os et overblik over, hvad humor egentlig er. Det oplagte træk er her, som altid, at søge mod den videnskabelige tradition - men det er desværre langtfra sådan, at et historisk overblik tegner et klart billede af, hvad humor er. Patricia Keith-Spiegel (1972) må således afslutte sit forsøg på at opsummere de historiske forsøg på at forstå humorens væsen med følgende konklusion²: "At præsentere en opsummering af humorens væsen ved at trække alle de spredte stumper sammen, som er revet fra hinanden gennem århundreder af teoretisering, ville, for at sige det mildt, være en umulighed" (Keith-Spiegel 1972: 34) ${ }^{3}$. Den nyere forskning har heller ikke leveret noget tydeligt overblik eller et begrebsapparat, 
som entydigt beskriver, hvad humor er - men enkelte hovedpunkter kan dog trækkes frem.

En af de tidligste opfattelser af humor, som kan spores i den filosofiske tradition, er opfattelsen af humor som en selvhævdelse, en triumf over, at vi er bedre end andre, som typisk kommer til udtryk i, at vi griner over andres ulykke, bruger latter til at fornedre andre og hæve os selv over det lave og gemene. Denne opfattelse kan findes hos Platon (i Philebus-dialogen), hos Aristoteles (i Poetikken) og hos senere filosoffer som Hobbes (i Human Nature) eller Bergson. I nyere tid er fortalerne færre, men de findes. Den mest indædte nutidige repræsentant for denne holdning er Gruner, som har udnævnt latterliggørelse (ridicule) til det mest grundlæggende element i al humor, og som mener, at triumf i kamp, mobning og nedgørelse af andre er den fylogenetiske baggrund for udviklingen af latter og humor (Gruner 1978, 1997). Det kan være svært helt at afvise, at der er en sandhed i dette. Men i betragtning af humors rolle i det positive samspil mellem mennesker og dens kobling til karaktertræk som munterhed, er det tydeligt, at dette i hvert fald ikke dækker alle former for humor ${ }^{4}$.

Den egentlige fællesnævner for de mange forskelligartede forsøg på at forstå humorens væsen, må være dens karakter af overraskelse. Det er en opfattelse, der som minimum kan spores tilbage til Descartes, Hobbes og Darwin (Keith-Spiegel 1972). Overraskelseselementet, som gang på gang er blevet fremhævet af humorforskere, bekræftes intuitivt af de omstændigheder, som omgiver vittigheden. En vittighed må være ny - ellers finder vi den ikke sjov. Derfor indledes fortællingen af en vittighed ofte med "Har du hørt den om ...?", da den vittighed vi allerede har hørt ikke længere er morsom. Det er fuldt ud muligt at sætte pris på vittigheder, vi allerede kender, men der er en væsensforskel på, hvordan vi reagerer på disse, i forhold til vittigheder, vi hører for første gang ${ }^{5}$ og man kan argumentere for, at der kun i sidstnævnte tilfælde er tale om egentlig humor.

Det nødvendige overraskelseselement i humor illustreres måske allerbedst af den mest forudsigelige, klichéagtige form for humor, vi overhovedet kender. De klassiske discipliner inden for den fysiske komedie, "glide i en bananskræl" eller "få en lagkage i hovedet", kan synes at være det mest forudsigelige af alt, idet vi ved præcis, hvad der skal komme, og kunne dermed siges at modsige 
overraskelsen som et nødvendigt element $\mathrm{i}$ humor. Her er det ikke selve gerningen, men derimod hvornår - eller hvordan - lagkagen afleveres, der udgør overraskelseselementet. Deraf kommer betydningen af den komiske timing, som er kendetegnende for al fysisk komik. Selv i denne form for humor, hvor selve handlingen er velkendt, er det således overraskelsen over, præcis hvornår dette foregår, som udløser humor - og jo mere uforudsigelig selve afleveringen af lagkagen er, jo større humor ${ }^{6}$.

Den grundlæggende model for humor er i denne forstand det at blive kildet. Vi kan som bekendt ikke kilde os selv, og det skyldes, at vi i denne situation ved præcis, hvornår den udløsende stimulus kommer. Dette er nok til, at vi ikke længere griner af at blive kildet. Men når stimuli kommer udefra, og dermed er uforudsigelig i sin natur, skal der ofte blot forventningen til, om at vi bliver kildet, for at udløse latter.

I den skriftsproglige humor, som er vores objekt i denne artikel, er denne timing naturligvis sat ud af spil, idet vi jo selv styrer den fremadskridende læsning. Overraskelsen må derfor skabes på anden vis, og da den eneste overraskelse, som synes mulig i læseprocessen, er præsentationen af noget materiale, som ikke umiddelbart passer ind i den sammenhæng, som vi er ved at etablere $\mathrm{i}$ læseprocessen, er dette kendetegnet for den sproglige humor. Dermed er pointen skabt - og i humorteorier beskrives denne typisk som præsentationen af en inkongruens - underforstået, mellem tekst og pointe.

\section{DET ER NOGET SOM IKKE STEMMER ...}

Opfattelsen af inkongruens som det grundlæggende element i humor går mindst tilbage til tyske filosoffer som Immanuel Kant (1790) - som etwas Widersinniges og Arthur Schopenhauer (1818) - som Inkongruenz ${ }^{7}$. Den simpleste inkongruens (eller modsætning) er ordspillet, som i sin grundkerne blot består af præsentationen af en tvetydighed, som skuffer vores forventning om, at en givet tekst kun kan læses på én bestemt måde. Denne type humor er typisk for situationskomik og forekommer hyppigt i de velkendte brandere (eller "onkelvittigheder") a la: 
I skriftsproglig humor er det rene ordspil mere sjældent, og kun få teorier antager, at den blotte præsentation af en tvetydighed er nok til at forklare humor. Den mest åbenlyse repræsentant for en sådan holdning er Arthur Koestler (1964), som opfattede humor som en samtidig oplevelse af to inkompatible situationer, som han døbte en bisociation. Dette passede som fod i hose med hans projekt, som var at koble humors mekanismer med kreativitet som jo netop ofte forløber som en kobling mellem to tidligere ubeslægtede begrebsområder.

Langt de fleste humorteorier tager dog afsæt $\mathrm{i}$, at tvetydigheden - den samtidige præsentation af to ubeslægtede begrebsområder - ikke er nok til at forklare humor. Den grundlæggende model for humor ses i stedet som et tidsligt forløb bestående af registreringen af en inkongruens, efterfulgt af en opløsning af denne inkongruens - som er den egentlige udløser af humor. Æren for denne model tillægges i dag typisk - måske noget arbitrært - Suls (1972), som vi derfor må henvise til her, selvom forestillingen om, at inkongruensen kræver en opløsning, før der bliver tale om humor, allerede var blevet foreslået af f.eks. Eysenck $(1942)^{8}$.

Suls' fortjeneste var primært at sætte fokus på, hvordan inkongruensen tænkes opløst i læsningen. Hans udgangspunkt for at forudsætte en sådan opløsning var, at tidligere inkongruensteorier efter hans mening ikke forklarer, hvorfor inkongruensen i sig selv skulle være forbundet med behag'. Ifølge Suls' model er det således genskabelsen af (en ny) kongruens, som opstår efter opdagelsen af den første inkongruens, som skaber selve humoren. Eller sagt med andre ord: humor er en toleddet proces, som forløber ved, at vores første læsning af vittigheden forstyrres af et fremmedelement (inkongruensen), som imidlertid ved en omfortolkning af den ramme, vi forstår teksten i, atter kan sættes i sammenhæng med teksten - og det er konstateringen af den på ny opståede overensstemmelse mellem pointe og tekst, som skaber det behag, som er karakteristisk for humor ${ }^{10}$.

Det er forholdsvis ligetil at finde eksempler i det empiriske materiale, som lader sig analysere ved hjælp af Suls' model. Følgende eksempler er taget fra den danske humorklassiker 560 humørpiller: 
(2) To damer med hver sin vovse i snor traf hinanden på en boenk i parken og kom naturligvis i snak om de kaere små dyr.

- Har deres hund noget stamtrae, spørger den ene i samtalens løb.

- Noeh, det kan man egentlig ikke sige. Den bruger forskellige troeer.

(3) - Min Viola har to af de skønneste ben i verden.

- Hvor ved du det fra?

- Jeg har talt dem.

Her er der tydeligt tale om, at en bestemt læsning fastholdes gennem det meste af vittigheden, indtil vi i den afsluttende sætning, pointen, tvinges til at forstå teksten på en anden måde. I (2) erstattes den etablerede ramme (afstamning) af en ny (urinering), centreret omkring en dobbeltbetydning af ordet "stamtræ". Der er altså i virkeligheden tale om en udvidelse af det simple ordspil, hvor der ikke bare præsenteres to samtidige betydninger, men i kraft af vittighedens tidslige forløb skiftes fra den ene læsning til den anden. I (3) er der en forventning om, at spørgsmålet drejer sig om, hvordan fortælleren kan vide, at Violas ben vitterlig er de skønneste ben i hele verden (han kan jo dårligt have set efter ...), som imidlertid erstattes af en besvarelse af, hvordan man er nået frem til antallet.

Et andet eksempel er det følgende fra Poul Erik Carstensens Etvorelses med spisetoilet. En stand-up encyklopaedi (1996), der præsenteres som "Danmarks første stand-up bog", og som indeholder en lang række korte, humoristiske sentenser under forskellige overskrifter. Under "SEX" finder vi følgende noget lakoniske konstatering:

Kvinder kan ikke lide sex. Det er i hvert fald min erfaring.

Et udsagn, som ved første øjekast udelukkende er af generel karakter, får en noget uheldsvanger personlig karakter, når det går op for læseren, at årsagen til at den stakkels mand har fået dette negative indtryk af kvinder, hænger sammen med hans egen manglende seksuelle formåen. 


\section{EN, TO, VENSTRE, HØJRE ...}

Den vigtigste eksperimentelle støtte for Suls' totrinsmodel stammer fra studier af forskelle i de to hjernehalvdeles bidrag til forståelsen af humor. I to nu klassiske studier af Howard Gardner, Hiram Brownell og kolleger blev Suls' model belyst hos hjerneskadepatienter, som blev sat til at vælge den rigtige slutning på forskellige vittigheder eller vittighedstegninger. Det indledende studie (Brownell et al. 1983) viste, at personer med hjerneskade i højre hjernehalvdel i forhold til testgruppen af normale patienter både havde svært ved at vælge den korrekte pointe og havde en tendens til at udvælge slutninger, som ikke etablerede nogen ny læsning af teksten, idet de ikke logisk kunne kobles til tekstens betydning (non-sequitur endings) - selvom de stadig var i stand til at vælge en slutning, som opfyldte vittighedens krav om, at den skulle indeholde en overraskelse. Det blev i forlængelse af Suls' model tolket sådan, at de godt kunne genkende behovet for overraskelse (inkongruensen) i vittigheden, men ikke var i stand til at skabe en ny sammenhæng ud af pointe og tekst.

Det efterfølgende studie (Bihrle et al. 1986) testede både personer med hjerneskader i højre og venstre hjernehalvdel, som blev bedt om at afslutte vittigheder som nedenstående - eller tilsvarende eksempler fra den danske tegneserie Ferd'nand, som udmærker sig ved ikke at indeholde tekst, og som i isolerede forsøg havde udvirket samme respons som de sproglige vittigheder:

(5) A woman is taking a shower. All of a sudden, her doorbell rings. She yells, "Who's there?", and a man answers, "Blind man." Well, she's a charitable lady, so she runs out of the shower naked and opens the door. The man says, "Where should I put these blinds, lady?"

Dette forsøg bekræftede resultaterne fra det forudgående, idet personer med hjerneskade i højre side tilmed viste en tendens til at vælge slutninger som indeholdt et element af fysisk komik. Derudover viste det, at personer med hjerneskade i venstre hjernehalvdel, til gengæld for at de var i stand til at skelne de slutninger som lå i logisk forlængelse (sequitur) af vittigheden, fra dem som ikke gjorde (non-sequitur), havde en tendens til - når de tog fejl af pointen - at vælge en slutning som var lige-ud-af-landevejen (sequitur), men ikke egentlig morsom, i stedet for en som indeholdt en overraskelse i pointen. De var med andre ord i stand til at integrere de forskellige elementer i en sammenhæng, men ikke altid i stand til at vælge den overraskende slutning. 
Resultaterne omkring de to hjernehalvdeles bidrag til humorforståelsesprocessen er blevet bekræftet af en række senere studier (f.eks. Shammi \& Stuss 1999), særligt af Seana Coulson (Coulson \& Kutas 2001, Coulson \& Lovett 2004, Coulson \& Williams 2005), som kobler forskellen mellem de to hjernehalvdeles bidrag til Mark Beemans Coarse Coding Hypothesis (Beeman 1994, Beeman \& Chiarolle 1998), som beskriver de to hjernehalvdeles tilgang til forståelse af sprog og verden som væsensforskellige: Mens venstre hjernehalvdel holder sig til lokale semantiske sammenhænge og regler, primært i en sekventiel orden, sætter højre hjernehalvdel i højere grad elementerne ind i en overordnet (global) forståelsesramme ${ }^{12}$.

Venstre hjernehalvdels væsentligste opgaver er at forudse næste trin i en handlesekvens, f.eks. også i en sætning, og er derfor naturligt involveret i at forudsige de følgende trin i den læsning, vi er i færd med. Det er primært denne forventning som skuffes i pointen, som til gengæld kræver bidrag fra højre hjernehalvdel, for at en omfortolkning af teksten skal kunne resultere i en ny dannelse af kongruens mellem pointe og tekst (Coulson \& Williams 2005).

\section{HUMORENS TIDSPARADOKS}

De mange studier af de to hjernehalvdeles bidrag til forståelsen af humor bekræfter opfattelsen af humor som en todelt proces, hvis elementer i særlige tilfælde kan observeres adskilt fra hinanden. I et af sine ERP-studier har Seana Coulson i samarbejde med Marta Kutas (2001) forsøgt yderligere at belyse Suls' totrinsmodel (1972) for humorforståelse. Coulson og Kutas benyttede sig her af det såkaldte N400-potentiale (Kutas \& Hillyard 1980), som er et mål for sværhedsgraden af at integrere et ord i en forståelsesramme (Kutas et. al 2000), som de tolker som et korrelat for andet stadie i Suls' model (som de her kalder coherence) $^{13}$. Forsøgene blev udført med vittigheder i stil med:

(6) Jeg spurgte bartenderen efter noget koldt med masser af rom i, og han foreslog mig sin kone (med normal kontrol: sin daiquiri)

(7) Hun havde loest så meget om de negative effekter af rygning, at hun besluttede at holde op med at loese (med normal kontrol: at ryge) - her i min egen fordanskning.

Resultaterne førte imidlertid ikke umiddelbart til en bekræftelse af Suls' populære totrinsmodel, idet de potentialer, som Coulson og Kutas tolker som udtryk for de 
forskellige led i forståelsen af det humoristiske udsagn, ikke fulgte hinanden i et tidsligt forløb, men forekom inden for den samme tidsramme ${ }^{14}$. Coulson og Kutas var derfor tvunget til at konkludere: "The temporal overlap of these jokerelated ERP effects thus makes it unlikely that joke processing can be accounted for in terms of a simple two-stage model with surprise and coherence engaged in sequence." (Coulson \& Kutas 2001: 74). Man skal naturligvis være varsom med at overfortolke sådanne resultater, men ikke desto mindre peger de på, at mens det er muligt at påvise den todelte struktur i humorforståelsen i de to hjernehalvdeles bidrag til processen, så er det langtfra uproblematisk at opfatte dette som et tidsligt forløb, bestående af en indledende inkongruens og en efterfølgende opløsning ${ }^{15}$.

I sin beskrivelse af humorens væsen kommer Rachel Giora (2003) med en delvis løsning på dette problem. I stedet for at opfatte det sådan, at den ene forståelsesramme erstatter den anden i et tidsligt forløb, sådan at den nye ramme først bliver konstrueret/aktiveret efter at vittighedens inkongruens er konstateret, foreslår hun, at man skal forstå det sådan, at de to læsninger eksisterer sideløbende, blot med forskellig "vægt" (salience). Det som sker, når pointen træder i effekt, er derfor, at den tidligere mindre vægtede læsning træder i forgrunden, og den tidligere mest åbenlyse (salient) læsning fortrænges til baggrunden ${ }^{16}$.

Det vigtige skift mellem de to læsninger foregår dermed ikke som en konstruktion af en ny ramme, men primært ved en undertrykkelse (suppression) af den tidligere mest åbenlyse læsning. Giora forklarer således det fundne N400respons som udtryk for denne undertrykkelse, snarere end som et udtryk for en egentlig forandring af forståelsesrammen. Hermed mener hun at løse et andet problem for Coulson og Kutas, nemlig at forklare hvorfor et sådant skift i forståelsesrammen (frame-shifting) tilsyneladende er forbundet med mindre besvær (mindre N400), når der ikke er tale om humor, end når der er tale om humor, idet denne undertrykkelse af den mest åbenlyse læsning netop er det, som adskiller humoren fra f.eks. ironi eller metafor, hvor begge læsninger bibeholdes ${ }^{17}$.

Gioras Graded Salience Hypothesis (1997) kan således bedre forklare det tidslige sammenfald af de potentialer, som i Coulsons og Kutas' ERP-målinger menes at 
korrelere med de forskellige led i Suls' model for humorforståelse - selvom den mangler at forklare, hvordan den læsning, som jo må præsenteres som en overraskelse, for at der overhovedet er tale om humor, allerede skulle kunne være aktiveret inden pointen (- kan en vittighed være fuldendt, hvis vi allerede på forhånd aner pointen?). Til gengæld giver den ikke noget entydigt svar på, hvorfor undertrykkelsen af den mest åbenlyse læsning fremkalder en humoristisk respons. Forklaringen herpå kan være, at det for at forstå humor til bunds er nødvendigt at forlade den ensidigt kognitive forståelsesramme.

\section{EMOTIONELLE TEORIER OM HUMOR}

Der er intet nyt under solen - og der er heller intet nyt $\mathrm{i}$ at fremhæve det emotionelle som et vigtigt element i forståelsen af humor. Eysenck (1942) skelnede således mellem humorens kognitive (cognitive) side, primært bestående af inkongruens og kontrast mellem idéer, og dens emotionelle (orectic) side, bestående af henholdsvis dens selvhævdende (conative) og dens affektive (affective) element ${ }^{18}$. Scheerer (1948) skelnede også mellem humorens kognitive og emotionelle sider, men opfattede primært denne skelnen som modsætningen mellem en objektiv og en subjektiv oplevelse af humoren - helt i tråd med den traditionelle opfattelse af kognition som almen og generel, og affekt som individuel og dermed variabel ${ }^{19}$. De teoretikere som vitterlig tilkender de emotionelle elementer en vigtig rolle i humoren, har dog historisk set enten set humor som et udtryk for en generel positiv holdning til livet eller som en udløsning af en psykisk energi.

Opfattelsen af humor som en udløsning af psykisk energi kan spores tilbage til Kant (1790), der beskrev latteren som "en affekt der opstår af den pludselige forvandling af en spændt forventning til intet" ${ }^{20}$. Den bliver dog først for alvor mål for en detaljeret beskrivelse hos Herbert Spencer (1860), hvis model for humor skal forstås $\mathrm{i}$ lyset af tidens forkærlighed for at bruge hydraulik som metafor for menneskelig tænkning. I analogi med tidens vigtigste teknologi, dampmaskinen, er humorens udløsning her at sammenligne med en lettelse af damptrykket gennem en sikkerhedsventil.

Spencers model videreførtes af psykoanalysens fader, Sigmund Freud (1905), som også forstår humor som en (pludselig) udløsning af en (over tid) ophobet psykisk energi. Denne opfattelse synes $\mathrm{i}$ enkelte tilfælde at være passende, som 
eksempelvis i de allerede nævnte komiske klassikere "glide i en bananskræl" eller "få en lagkage i hovedet", hvor man på forhånd ved, hvad der vil ske, men ikke hvornår selve handlingen (udløsningen) vil finde sted - og derfor netop kan tale om en opbygning af en forventning, som kulminerer i handlingens udførelse. Disse eksempler er dog langtfra typiske for humor generelt - og slet ikke for sproglig humor. Den optimale timing i den sproglige vittighed synes utvetydigt at være at inkongruensen (som man må forestille sig opbygger den psykiske energi) og dens opløsning begge etableres isoleret i pointen - som helst skal falde så sent og så kortfattet som muligt.

Som Giora (2003) påpeger, er det en essentiel del af en vittigheds opbygning, at vi bliver ledt i én bestemt retning, som til at starte med er utvetydig, og at denne entydighed er bibeholdt (retention) helt frem til pointen, hvor overraskelsen, inkongruensen, der tvinger os til en omfortolkning af hele vittigheden - som for Giora består i en undertrykkelse (suppression) af den hidtidige fortolkning præsenteres ${ }^{21}$. De teorier, som forsøger at beskrive humor som en udløsning af en i forvejen ophobet psykisk energi, står således i endnu højere grad end Coulson og Kutas (og deres fortolkning af Suls' totrinsmodel) overfor problemer med den tidslige ramme, idet det netop er karakteristisk for den vellykkede sproglige vittighed, at der ikke introduceres nogen inkongruens eller tvetydighed før til allersidst, tidsmæssigt sammenfaldende med udløsningen ${ }^{22}$. Nok sker der $\mathrm{i}$ pointen en skuffelse af en opbygget forventning - men denne forventning er netop ikke en psykisk spænding, men derimod blot den konventionelle fortsættelse af den læste sætning, som næppe er forbundet med en ophobning af psykisk energi - man kunne måske endda sige tværtimod ${ }^{23}$.

De fleste nyere undersøgelser af humorens emotionelle grundlag baserer sig på humorens karakter af morskab og fornøjelse. Denne opfattelse har også gamle rødder, men har i nyere humorforskning primært været fremtrædende i beskrivelser af sammenhængen mellem karaktertræk og humor. Her har der vist sig en tydelig tendens til, at humoristisk sans hænger sammen med et generelt positivt livssyn og optimisme (Svebak 2000), betegnet "munterhed" (cheerfulness) (Martin 1998, Ruch \& Köhler 1998). Munterhed er direkte korreleret med humoristisk sans, dvs. sandsynligheden for, at man vil grine af humoristisk materiale, både som øjeblikkelig tilstand (state cheerfulness) og som generelt karaktertræk (trait cheerfulness) (Ruch 1997). 
At netop karaktertræk eller aktuelle tilstande forbundet med munterhed og livsglæde er gunstige for humorens udfoldelse modsiger "udløsningsteorien", idet det viser, at den typiske tilstand forbundet med humoristisk sans er livsglæde og leg, ikke en form for ophobet psykisk spænding, som trænger til forløsning. Freuds idé om, at humor primært udløses af fortrængte følelser, er derfor ikke den mest åbenlyse fortolkning af humor. Grundtilstanden for humor er den glade disposition, og munterhed er den emotionelle ramme, som er mest gunstig for udløsning af humor, ikke nervøsitet eller psykisk spænding. Faktisk tyder alt på, at den latter, som udløses af nervøsitet eller spænding, er af en fundamentalt anden karakter ${ }^{24}$, end den egentlig muntre, og udløsningsteorien kan dermed i Freuds udgave næppe anses for at være et særlig godt bud på en generel teori om humor.

\section{Det BeHAGELIGE UBEHAG}

Mens munterhed - som talrige studier af sammenhængen mellem karaktertræk og humoristisk sans har påvist - synes at være humorens forudsætning, er der imidlertid en risiko for, at et for snævert fokus på munterhed som det emotionelle grundtræk i humor, kan få os til at overse en vigtig detalje. For nok er munterhed humorens forudsætning, men er den nok til at forklare humorens udløsning? Eller skal munterhed snarere opfattes som en emotionel ramme, inden for hvilken humor - som måske udløses af helt andre faktorer - optræder?

Som William Fry (2002), i sin gennemgang af studier, som ikke primært har haft humor som deres sigte, men som alligevel kan relateres til humorforskning, understreger, er oplevelsen af humor ikke entydigt koblet til oplevelsen af behag $^{25}$, men indeholder tværtimod en spænding mellem det behagelige og det ubehagelige, en ambivalens, som ikke kun er et væsentligt element i humor, men måske selve dens drivkraft. ${ }^{26}$

Denne ambivalens udkrystalliserer sig tydeligst i den såkaldte "falde på halen"komik (slapstick), hvor balancen mellem humors positive og negative pol står tydeligt frem. Den form for komik - som blandt andet er det væsentligste element i de mange fraklips- og hjemmevideo-shows, som har været vist på tv i de seneste årtier - har to grundlæggende forudsætninger: 1) den handler om ulykke, om personer der snubler, falder eller på anden måde tilsyneladende kommer til skade eller i problemer, og 2) den forudsætter, at denne ulykke 
forekommer inden for en ramme, hvor den ikke er truende for tilskueren hvilket i udvidet forstand indebærer, at også aktøren selv er uskadt (Ramachandran 1998). At det er en grundlæggende forudsætning for fysisk komik, at den skade vi ser, ikke er alvorlig, kommer også til udtryk i, at aktøren ofte optræder i et ritualiseret kostume, som f.eks. klovnen med den røde næse, de store sko og det hvide tøj - hvor evt. blodstænk øjeblikkeligt ville kunne ses eller klassikere som Gøg og Gokke eller Fyrtårnet og Bivognen, som i vidt omfang er karikerede figurer - for at understrege, at vi er vidne til en forestilling og ikke virkelighed $^{27}$.

Men selvom balancen mellem ubehag (fare) og behag (tryghed) er åbenlys i den fysiske komedie, hvordan kommer denne så til udtryk i den sproglige form? Kan man overhovedet drage en parallel fra den fysiske komedies blanding af ubehag og behag, af indlevelse i faren og den efterfølgende erkendelse af, at situationen er ikke-truende, til sproglig humor? Svaret på dette spørgsmål vil vi søge i en dansk nyklassiker i humorgenren, nemlig Anders Lund Madsens Madsens ÆØØ̊ (1997).

Madsens $Æ Ø \AA ̊$ er (som det skrives på bagsidecoveret) en "ordbog over ting, som der sjovt nok endnu ikke findes ord for", og er en alfabetisk liste over nyopfundne betegnelser for situationer eller genstande, som endnu ikke har noget navn. Idéen er - som det er angivet på copyright-siden, og som Anders Lund Madsen selv gør opmærksom på i sit forord - stjålet fra Douglas Adams' og John Lloyds The Meaning of Liff (1984), hvor de nye betegnelser var genbrug af allerede eksisterende bynavne, mens Anders Lund Madsen i stedet har anvendt kunstsproget Volapük som udgangspunkt for sine nye begreber. Typiske eksempler er:

(8) Bifoin (adj): Den lettere ubehagelige fornemmelse, som man får af at saette sig på et toiletsaede, som stadig er lunt efter den tidligere gaest. ${ }^{28}$

(9) Jemodik (s): Landbrugsredskab der påspoendes en traktor og gør det muligt for landmanden at sprede gødningen $i$ et joevnt lag $i$ hele vejens bredde.

(10) Kastof (s): En vidunderlig kvinde med langt bølgende mørkt hår og en nydelig formspoendt bagdel som viser sig at voere en mand, når du omsider er nået op på siden af hans cykel.

(11) Faséd (s): Den kombinerede spaending og skam man føler, når man bliver afsløret på et offentligt sted, mens man plukker noesehår og gemmer dem $i$ brystlommen. 
Udvalget er naturligvis stærkt tendentiøst - som det må være, når man uddrager en håndfuld eksempler fra en bog med over 1.000 ordforklaringer - men det understreger et gennemgående træk ved Anders Lund Madsens værk. Ved hjælp af sproget beskriver - og dermed fremkalder - han en situation, som indeholder et vist ubehag (eller en blanding af behag og ubehag) i kraft af en social pinlighed (11), et kropsligt ubehag (8, 9), eller en spænding mellem den emotionelle motivation og virkeligheden (10). Denne genkaldelse af genkendelige situationer er grundkernen i megen humor, f.eks. også stand-up som Povl Erik Carstensen skriver:

\section{Kender I det? kunne egentlig voere overskriften på al stand-up. [37]}

De to vigtigste ingredienser er her genkendelsen af en situation og oplevelsen af denne situation som forbundet med et ubehag - hvad enten dette skyldes, at den indeholder et fysisk ubehag, en socialt pinlig eller uacceptabel adfærd, eller relaterer til emner, som er tabubelagt eller ikke hører til i "det gode selskab". Det er således langtfra tilfældigt, at humor traditionelt har beskæftiget sig med det tabubelagte, det farlige, det som man ikke tør tale om, osv. - eller at stort set al stand-up handler om sex, som, trods vores seksuelle frigørelse, i vidt omfang stadig er omgærdet af socialt tabu. Blot antydningen af, at et udsagn kan tolkes seksuelt, er ofte nok til at udløse humor - som i den klassiske værkstedshumors evigt gentagne kommentar: "Det sagde hun også i går!".

Det er værd at bemærke, at mange af de eksempler, som er blevet brugt i den videnskabelige undersøgelse af humor, og som derfor er at finde $\mathrm{i}$ den videnskabelige litteratur omkring humor, på trods af at de fremstilles som rent sproglige vittigheder, indeholder sådanne referencer til pinlig eller uacceptabel social adfærd, som f.eks. det at vise sig nøgen for fremmede (5), at tilbyde sin kone til fremmede mænd (6), eller - måske værst af alt - at nævne kvinders emotionelle ustabilitet i forbindelse med graviditet og fødsel ("By the time Mary had her fourteenth child, she'd run out of names to call her husband." (Coulson \& Lovett 2004: 286)).

Hvis man fører disse overvejelser til ende, betyder det at den grundlæggende model for humor ikke er Suls' totrinsmodel, men derimod pruttehumor (som - 
modsat hvad mange tror - netop ikke er universel, men netop kræver, at en prut opfattes som socialt uacceptabelt for at udløses). Humoren består således i den pludselige ("PRUUUUT!") introduktion af noget potentielt truende - eller i det mindste socialt uacceptabelt - i en social situation, hvor det dog alligevel ikke udgør nogen direkte fysisk trussel; selvom prutter lugter, er gasudslippet jo sjældent livstruende! Og det er trods alt sjældent, man hører om, at personer er blevet straffet for at prutte. Pruttehumor er naturligvis også repræsenteret i Madsens ÆØØ:

(13) Metafüsud (s): En soerlig voldsom form for luft i tarmene som soerlig rammer folk, når de efter et større måltid sidder og slapper af i en toetpakket biograf.

(14) Laud (s): En slags prut som du håber folk vil overdøve med snak.

(15) Eventuo (s): Den ufrivillige mave-rumlen, der fylder tavsheden efter at en anden $i$ selskabet netop har afsløret noget meget intimt og personligt om sig selv.

Det ufarlige i situationen, som er en forudsætning for latterens udløsning, består her primært i, at man, i kraft af at Anders Lund Madsen er kendt som humorist og komiker - "en lystig fætter", i læsningen allerede er sat ind i en ramme, hvor man forventer, at det hele foregår i en ikke-truende, munter atmosfære. Selve læsesituationen bidrager naturligvis også hertil, idet det er sjældent, at vi formår at føle os fysisk truet af en tekst vi læser. Det samme gælder, når vi er taget ind for at se en stand-up-komiker som f.eks. Povl Erik Carstensen, og bliver forstærket af, at arketypen på en stand-up-komiker (som Anders Lund Madsen også passer ind i) er den lidt kiksede, klodsede og selvironiske type, som beretter om sine fejlslagne score-tricks og genvordigheder i verden (4) - en på alle måder ikke-truende adfærd, både fysisk og socialt - og ikke en selvhævdende, aggressiv type, som kunne opfattes som en fysisk og social trussel.

\section{HUMOR, SPROG OG VIRKELIGHED}

De ovenfor nævnte sproglige eksempler snyder naturligvis på vægtskålen, i den forstand at de udløser humoren ved at referere til en situation, som ligger uden for sproget. Men samme effekt kan faktisk skabes inden for sproget. Det er her inkongruens kommer ind, som en erstatning for det ubehag, som i de nævnte eksempler fremkaldes ved hjælp af ydre referencer. Inkongruens kan siges at være forbundet med et ikke ubeslægtet ubehag i kraft af sin status som skuffelse, i og med at inkongruens optræder som et brud med den læsning, den forståelse 
af det sproglige budskab, som vi er ved at konstruere. Dette burde naturligvis i princippet kunne foregå fuldstændig tekst-internt, udelukkende ved at de sproglige elementer ikke længere passer sammen som forventet, men da dette ville ændre tekstens status som forståelig tekst, foregår det i stedet typisk som en skuffelse af forventningen om overensstemmelse mellem sprog og virkelighed. Humor udløses altså ikke som en mekanisme internt i sproget, men i forholdet mellem sprog og virkelighed.

Heller ikke denne idé er ny, men findes allerede hos Arthur Schopenhauer, som i sit hovedværk Verden som vilje og forestilling (1818) giver den måske til dato mest koncise beskrivelse af den sproglige humors mekanismer, som derfor fortjener at blive citeret i sin helhed (2006: 142):

\begin{abstract}
"Latter opstår hver gang ikke af andet, end den pludselige registrerede inkongruens mellem et begreb og de reale objekter, der blev tænkt med dette begreb i en eller anden forbindelse, og latteren er selv netop blot udtryk for denne inkongruens. Den fremkommer ofte, fordi to eller flere reale objekter tænkes gennem et begreb, og dette ene begrebs identitet overføres på alle objekterne. Hvorefter en total forskel mellem objekterne i øvrigt gør det påfaldende, at begrebet kun passede på dem i en ensidig henseende. Lige så ofte skyldes latteren imidlertid, at man pludselig mærker et enkeltstående realt objekt ikke kongruerer med et bestemt begreb, som objektet på den anden side er blevet subsumeret under. Jo rigtigere subsumtionen af sådanne virkeligheder under et bestemt begreb er på den ene side, og jo større og mere grel uoverensstemmelsen er mellem dem og begrebet på den anden side, desto stærkere bliver det lattervækkendes virkning, der netop udspringer af denne modsætning. Enhver latter opstår altså som følge af en paradoksal og derfor uventet subsumtion, og det er lige meget, om den udtrykkes gennem ord eller gennem handlinger. Dette er i korte træk den rigtige forklaring på det lattervækkende."
\end{abstract}

Schopenhauers beskrivelse forklarer både ordspillet (flere reale objekter tænkt gennem ét begreb), og vittigheden (en pludselig inkongruens mellem et objekt og det begreb, som det er blevet subsumeret under), som altså ikke skal ses som en omfortolkning fremprovokeret af en pludselig registrering af inkongruens, men derimod som en spænding mellem en lovmæssig (typisk sproglig ${ }^{29}$ ) korrelation mellem objekt og begreb (tilvejebragt via subsumtionen), og den opståede uoverensstemmelse mellem det reale objekt - eller vores erindring om det - og dette begreb. Humors vigtigste element er dermed en relativering af forholdet mellem sprog og virkelighed. 
Tilbage står blot at forklare, hvorfor dette resulterer i en emotionel reaktion, en affekt. Inden for en fortolkningsramme, som udelukkende søger at forklare forholdet mellem sprog og virkelighed gennem kognitivt modelbyggeri, og hvor vores følelsesmæssige reaktioner spiller en underordnet - hvis overhovedet nogen - rolle, er dette naturligvis i bund og grund uforståeligt. Hvis følelser og emotioner imidlertid anskues som andet end blot uforklarlige epifænomener, må ræsonen bag deres funktion naturligvis være koblet til den indsamling af viden, som for et intelligent, primært kortikalt styret pattedyr som mennesket, er den vigtigste biologiske overlevelsesfaktor. I dette lys er det klart, at erkendelsen af sprækker i forholdet mellem virkeligheden og vores begrebsliggørelse af den, må skabe en (negativ) emotionel effekt - som et udtryk for motivation til at udbedre dette misforhold.

Hvordan stiller dette Suls' kognitive totrinsmodel (som han selv kalder information-processing)? Jo, i stedet for at beskrive humorforståelse som et forløb af inkongruens og efterfølgende opløsning, må vi anskue de to led som forudsætninger for humors udløsning. Det er således registreringen af et misforhold i forsøget på at skabe mening med læsningen (inkongruens), sammenholdt med en konstatering af, at de lovmæssige (sproglige) regler for sætningens forståelse er overholdt (stadie 2), som tilsammen udgør den sproglige humors mekanisme. En sådan konstatering af, at vores sproglige forståelse af verden ikke længere er brugbar, må naturligvis fylde os med uro, om ikke decideret rædsel - hvis ikke det var fordi, den udfolder sig i en ramme (læsningen, den sociale situation, etc.), hvor vi kan konstatere, at den ikke udgør nogen umiddelbar fysisk trussel - og den derfor i stedet udløser den emotionelle respons, som i selskab med andre udtrykker sig som latter.

Det andet stadie - som i Suls' model beskrives som "problemløsning" (problemsolving) - udgør dermed ikke nødvendigvis opløsningen af den forudgående inkongruens, hvorfor de to trin sagtens kan (omend ikke nødvendigvis må) forløbe samtidig og sideløbende - hvilket forklarer Coulson og Kutas' ERPresultater (2001). Humor udløses dermed ikke af det tidslige forløb af inkongruens og efterfølgende opløsning, men af konstateringen af en forståelsesmæssig inkongruens inden for en ramme, som sprogligt set er intakt. 
De to led i Suls' model udgør således ikke tidslige stadier, men forudsætninger for humor. Hvis andet stadie eksempelvis ikke er overholdt, og pointen falder uden for mulighederne for at skabe sproglig kongruens, ændrer det således den ramme, hvori vittigheden forstås. De sproglige regler må være overholdt, med mindre det hele skal blive forvandlet til ufarlig nonsens-komik - noget usammenhængende vås som ikke umiddelbart giver nogen mening, og som selvom visse personer har en vis forkærlighed for denne form for humor - ikke aktiverer den samme spænding mellem sprog og virkelighed - og derfor generelt set heller ikke opfattes som lige så sjovt, som humor der "overholder reglerne".

Første led, inkongruensen (mellem sprog og virkelighed), kan til gengæld erstattes af introduktionen af et element, som fremkalder samme grad af ubehag (f.eks. ved henvisning til en social pinlighed), som erkendelsen af sprækker i forholdet mellem sproget og den verden, det skal beskrive. Men da der i begge tilfælde er tale om en form for forskrækkelse, er det under alle omstændigheder en forudsætning, at præsentationen af dette element sker pludseligt, da vi ikke bliver forskrækkede af ting, som vi kan se komme på lang afstand - bogstaveligt, såvel som metaforisk. Sproglig humor er således en sprængfarlig cocktail af regelbrud (i forholdet mellem sprog og virkelighed) inden for en regelret (sproglig, kognitiv) ramme.

Med denne udvidede model for sproglig humor i bagagen, kan vi pludselig analysere og forstå et langt større materiale, end kun håndplukkede vittigheder, som opfylder Suls' totrinsmodel. Det første af de nedenstående eksempler er fra Povl Erik Carstensen, under overskriften "SPØRGSMÅL", de øvrige fra glasset med de 360 Humørpiller:

(16) Hvad siger Ole Lukøje, når fru Lukøje spørger, hvordan det er gået på arbejdet?

- Ad helvede til. Jeg har ikke lukket et øje hele natten.

(17) - Vil du toenke dig, koere Klara. Først i dag får jeg at vide, at min mand har vaeret stum i tre uger. Han har ikke noevnt det med et ord!

(18) Fru Mortensen besøger sin mand i statsfoengslet.

- Hvordan klarer du dig økonomisk, spørger han bekymret.

- Jotak, det går helt godt. Jeg har jo dusøren.

(19) - Hvad var MacSenneps sidste ønske?

- At to liter whisky blev hoeldt over hans grav. 
- Opfyldte I virkelig det?

- Ja, naturligvis. Men vi gik ud fra, at han ikke kunne have noget imod, at vi filtrerede det igennem nyrerne først.

(20) Elefanterne og musene spillede en spoendende fodboldkamp $i$ urskovens semifinale, da en af elefanterne kom til at traede musenes målmand ihjel.

- Det skal du såmoend ikke vaere ked af, sagde musenes anfører. Det kunne jo også vore sket for en af os.

Man kan diskutere, hvorvidt der i disse tilfælde overhovedet introduceres nogen inkongruens, og om der dermed overhovedet er behov for nogen omfortolkning af vittigheden efter læsning af pointen. Vigtigst er dog, at det egentligt sjove i alle tilfælde ikke synes at være, at vi først skuffes i vores læsning, og derefter bekræftes i en ny fortolkning. Ingen af eksemplerne bryder således radikalt med den igangværende læsning. I (19) er det således introduktionen af et socialt tabu (at pisse på en anden mands grav), i (20) det fysisk umulige i den handling, som ellers inden for vittighedens sproglige logik virker så naturligt, i (17) det åbenlyse misforhold mellem konens kritik af manden for noget, han ikke kan have skyld for, i (18) den pludselige erkendelse af, at konen har brudt en (socialt) forventet loyalitet over for sin mand, og i (16) det bizarre i, at det svar, som vi er så vant til, betyder noget helt særligt ("jeg har ikke kunnet sove"), pludselig antager en helt, helt anden betydning inden for vittighedens univers, der får os til at grine. Det er også kun sådan, vi kan forklare et eksempel som det følgende, som jeg personligt synes er så langt det morsomste fra Poul Erik Carstensens samling:

(21) Jeg købte engang en maskine der lavede pusterør. Så kom jeg til at vende stikket forkert og lavede 20.000 sugerør. [10]

De sproglige regler er overholdt, og vittigheden synes endda - ligesom (16) - at følge sin helt egen sære logik (modsætningen mellem pusterør og sugerør). Men det er på ingen mulig måde sådan, at pointen ("opløsningen") skaber nogen på nogen måde brugbar eller logisk forståelig virkelighed eller læsning. Som humorforskerne udmærket er klar over, er der utallige eksempler af denne type, hvor opløsningen netop ikke tildeler sætningen nogen ny og brugbar mening, endsige formfuldendt kongruens - $\mathrm{i}$ anden forstand, end at pointen sprogligt set er mulig. Ofte efterlades vi i et tomrum, hvor sætningen ikke synes at udsige noget virkeligt om vores verden, men i stedet etablerer sin egen besynderligt 
logiske verden. Det gælder f.eks. også når Thomas Hartmann i sit stand-up-show Hartmann 3 (2006) stiller følgende spørgsmål:

Hvis man stjoeler mad fra en grønloender, kan man så kaldes en spoekhugger?

Såvel inkongruensen - der altså skal opfattes som en inkongruens mellem virkeligheden og vores sproglige repræsentation heraf - som "genskabelsen" af kongruens (konstateringen af, at det hele foregår inden for regelret sprogbrug) er altså ikke primært trin i et forløb, men forudsætninger for humors udfoldelse nøjagtig ligesom den muntre ramme. Derfor kan deres effekt ikke beskrives fyldestgørende i en kognitiv model, hvis paradigme er algoritmen - et sekventielt forløb af diskrete tilstande, reguleret af lokale regler - men beskrives bedst $\mathrm{i}$ form af etableringen af globale tilstande: munterhed, ambivalens, regeloverholdelse (egentlig: manglende regelbrud). Anvendelsen af globale tilstande - frem for lokale, sekventielle forløb - som beskrivelse er netop karakteristisk for vores traditionelle opfattelse af det emotionelle som modsætning til det kognitive ${ }^{30}$. Vi gør derfor bedst i at kalde humors elementer emotionelle - og det er da også sådan, vi oplever dem.

\section{HVOR KOMMER HUMOR FRA?}

Opfattelsen af humor som en oplevelse af en ubehagelig, pinlig, paradoksal eller potentielt truende stimuli i en tryg (dvs. ikke-truende) ramme er naturligvis ikke en ny opfindelse. Allerede Guthrie (1903) mente at humor, eller "fornøjelse" (amusement), opstår i en disharmonisk situation, hvis - og kun hvis - vi samtidig er overbevist om, at alt er "i orden" (all right) ${ }^{31}$. Også Mary Rothbart (1976) har understreget, at inkongruens (som må være latterens anstødssten for at blive til humor) må forekomme i en sammenhæng, som er behagelig, tryg og ikketruende.

Langt de fleste teorier, som har sat fokus på den trygge (ikke-truende) ramme, har imidlertid forstået denne som koblet til leg - som modsætning til alvor. Pointen i denne forståelse er, at de potentielt farlige oplevelser opfattes humoristisk, fordi det hele foregår i en ramme af useriøsitet og leg - hvilket passer udmærket med munterhed som humors typiske karaktertræk. Hermed bliver grundmodellen for humor den form for fysisk leg, dvs. afprøvning og træning af biologisk værdifulde handlemønstre i en ikke-alvorlig social ramme, 
der er typisk for pattedyr - og som dermed i sidste ende må ses som humors evolutionære oprindelse (Gervais \& Wilson 2005).

Den sociale tryghed, som er forbundet med leg (og som - i parentes bemærket er det, som negerer den potentielle fare, som opstår, når vi overraskes i humor) er således essentiel i Paul McGhees beskrivelse af humor (1979). For McGhee er humor primært en leg med ideer eller ord - som i den sproglige humor. Han beskriver således (1971), hvordan humor hos børn kan udløses helt uden nogen "opløsning" af inkongruenser (jf. Suls' totrinsmodel) - oplevelsen af inkongruens i en tryg ramme er nok. Selvom vi som voksne normalt kræver lidt mere, før vi griner (f.eks. oplevelsen af utilstrækkeligheden af vores begrebsapparat), kan man $\mathrm{i}$ dette lys $\mathrm{i}$ en vis forstand anse humor som udsprunget af og koblet til ufarlig leg - og tilmed bruge dette som argument for ikke at tage den alvorligt. Det er dog også muligt, at humor har langt videre betydning end som så.

I et af de seneste forsøg på at belyse humorens væsen ved hjælp af moderne hjerneskanningsteknik (fMRI) forsøgte Watson, Matthews og Allman (2007) at finde ligheder og forskelle mellem sprogbaseret humor og visuelt baseret humor. De anvendte avistegneserier - dels et udvalg af forskellige forfattere og tegnere fra avisen The New Yorker og dels et udvalg af The Far Side af Gary Larson. Ikke overraskende, fandt de en forhøjet aktivitet i de områder, som tager sig af visuel forarbejdning ved tegneserier, som baserede sig udelukkende på visuelle stimuli, mens de fandt en forhøjet aktivitet i venstre hjernehalvdels klassiske sprogområder i de tegneserier, som baserede sig på forholdet mellem tekst og tegning. Dette blev tolket som et udtryk for, at de to forskellige typer udløste et øget behov for analyse fra disse områder i hjernen for at forstå vittighedernes pointe.

Hovedargumentet for forsøget var imidlertid en forventning om at finde en forøget aktivitet $\mathrm{i}$ to særlige områder af hjernen, gyrus cingularis anterior og fronto-insular kortex, som indeholder en særlig type neuroner, de såkaldte Von Economo-celler, som en af forfatterne, John Morgan Allman, tidligere havde påvist hos mennesker og menneskeaber. Disse celler antages at være opstået for ca. 15 millioner år siden og understøtter dermed den traditionelle forestilling om, at humor er en særlig menneskelig - eller i dette tilfælde: en 
menneskeabelig - foreteelse. Denne forventning blev mere end opfyldt, idet graden af oplevelse af humor faktisk korrelerede med aktiviteten i disse områder.

Udover dette fund, fremhæver forfatterne desuden en forøget aktivitet i amygdala, som de ser som et led $\mathrm{i}$ en omfortolkning af tegneseriens belønningsværdi (reward value), som opfattes som koblet til Suls' andet stadie (som de her kalder reinterpretation). Dermed giver de udtryk for den traditionelle opfattelse af humor som koblet til positive følelser, idet de henholder sig til, at amygdala i de senere år i flere studier er blevet koblet til andre og mere positive følelser, end den frygt, som aktivitet i amygdala traditionelt er blevet set som et korrelat for ${ }^{32}$.

Spørgsmålet er blot, om forfatterne her kan være blevet forblændet af vores traditionelle opfattelse af humor som en ensidigt positiv oplevelse? Mens det er fuldt ud muligt, at aktiviteten i amygdala kan ses som et led, som indgår i skabelsen af en positiv oplevelse, så er det lige så muligt at fortolke amygdalaaktiviteten på traditionel vis, hvor den er koblet til frygt og ængstelse, eller blot årvågenhed (arousal), som det vigtigste led i hjernens alarmsystem (LeDoux 1999 $)^{33}$. Eller sagt på en anden måde: amygdala-aktiviteten er næppe blot udtryk for en positiv oplevelse, idet amygdala-aktivitet også er typisk ved tvetydigheder, læsning af følelsesladede ord, inkongruens (mellem ord og billede), responskonflikter, samt enhver form for emotionel konflikt (Etkin et al. 2006). I stedet for at gisne om, hvorvidt oplevelsen af aktivitet $\mathrm{i}$ amygdala er positiv eller negativ, bør vi måske i stedet bemærke, at amygdala typisk udviser aktivitet ved netop den type inkongruenser, som er typisk for humor - og, som vi kun kan formode, er forbundet med et vist potentielt ubehag.

Dette ville til fulde kunne forklare, hvorfor humor netop resulterer i øget aktivitet i amygdala og gyrus cingularis anterior (GCA) - samt områder i og omkring insula, som bl.a. udgør et bindeled mellem GCA og signalerne fra kroppens indre - som fællestræk ved forskellige former for humor. Amygdalaaktiviteten afspejler de forskellige former for inkongruens, som kan skabe det element af ubehag, som er et nødvendigt element i humor, mens aktiviteten $i$ GCA uden større problemer kan tolkes som et udslag af modsætningen mellem den pludselig opståede, tilsyneladende truende situation, og den generelle tilstand af velvære og tryghed. Det er her væsentligt, at GCA ikke blot er aktiv 
ved responskonflikt eller ved opløsningen af emotionelle konflikter (Etkin 2006), men også er ansvarlig for vores opfattelse af den "sociale situation" - og samtidig er et essentielt element $i$ vores sociale signalsystem, og f.eks. er kendt som det sted, hvorfra vores "ægte" følelsesudtryk - f.eks. det "ægte" smil (eller Duchennesmilet) - udløses.

I denne sammenhæng er det ikke uvæsentligt, at et andet fMRI-stuide (Etkin et al. 2006) har påvist, at netop GCA er involveret i at dæmpe responsen i amygdala i tilfælde af sådanne konflikter ${ }^{34}$. Det er derfor langt fra udelukket, at man heri med tiden kan finde et direkte neurologisk korrelat for humors mekanismer, som - i lyset af ovenstående - måske bedst beskrives som "den pludselige introduktion af en påvirkning, som kan virke truende i kraft af sin natur, sin sociale betydning eller sin tvetydighed (aktivitet i amygdala), i en situation, hvor vi føler os trygge og ikke umiddelbart truet, og hvor denne påvirkning derfor kan fortolkes som fysisk ufarlig (aktivitet i GCA, som leverer en vurdering af den aktuelle sociale situations karakter, samt en vurdering af situationens biologiske betydning for os - gennem insula, som modtager signaler fra kroppens indre) ${ }^{\prime 35}$.

Er denne tolkning korrekt, har humor langt større betydning, end blot som umoden lege-adfærd, som har overlevet op i voksenalderen. I så fald kan humor placeres som en væsentlig brik i den tendens til at søge viden om netop de ting, som udgør en potentiel trussel, som er karakteristisk for pattedyr. Som dokumenteret utallige steder, eksempelvis i Bræstrups klassiker Hjortebogen (1952: 82), er det (mod forventning?) ikke normalt for pattedyr at flygte ukritisk fra farer, som f.eks. rovdyr. Enhver flugt fra fare er jo forbundet med omkostninger i form af energiforbrug og risiko for, at man blot ender i større fare. Derfor er der en generel tendens til hos pattedyr at udforske det potentielt farlige, sådan at der kan skelnes mellem det, man bør flygte fra, og det som i øjeblikket er ufarligt ${ }^{36}$. Man bør her bemærke, at ethvert element i dyrets omverden, som ikke umiddelbart kan rubriceres i en af de to kategorier, altid er potentielt farligt - og derfor må undersøges. Den mætte løve får derimod ikke nødvendigvis zebraflokken til at flygte.

Hos mennesket er den trussel, som skal beherskes imidlertid ikke primært rovdyr eller ydre trusler, men af indre, social karakter. Den største trussel mod 
mennesket har altid været mennesket selv, og den største fare, vi står overfor er dermed altid, at den sociale balance, borgfreden, kan risikere at kollapse, hvis vi ikke er varsomme. Hvor hjorten skal lære at takle truslen fra rovdyrene uden at gå i panik, har humor sandsynligvis udviklet sig hos mennesket som et våben til at takle potentielt truende sociale situationer (Gervais \& Wilson 2005, Provine 2000), som ofte opstår i forbindelse med typiske sociale tabuer som sex eller aggression - humors vigtigste drivkraft.

\section{KONKLUSION}

Der er i en vis forstand intet nyt i ovenstående beskrivelse af humorens væsen. Alle elementer som indgår, har tidligere været foreslået eller beskrevet i teorier om humor. Det nye er udelukkende forsøget på at samle disse spredte elementer til en samlet fremstilling, der udviser bredde nok til at kunne rumme de mange forskelligartede opfattelser af humor, som er opstået gennem de forskellige forskeres afdækning af de dele af humorens væsen, som passer ind i deres teoridannelse.

Når sådanne synteser (sml. Gervais \& Wilson 2005) synes påkrævet netop nu, så skyldes det, at snæversynede teorier (som holder sig inden for de afstukne faggrænser) ofte kommer til kort over for de udfordringer, som vi står overfor i bestræbelserne på at koble forståelsen af vores opfattelse af sprog og virkelighed med den naturvidenskabelige hjerneforskning. Sådanne mere snævre teorier har (selvom man kan nære en mistanke om, at de primært anvender humor til at belyse egne teorier - f.eks. Gioras Graded Salience Theory (Giora 2003) eller Coulsons Frame-shifting (Coulson \& Kutas 2001) - snarere end at bruge teorien til at belyse humorens væsen) naturligvis leveret vigtige bidrag til forståelsen af humors mekanismer. Men nye tider kræver nye tilgange, og i denne situation er der - efter min bedste overbevisning - brug for tilgange, som i langt højere grad formår at belyse samspillet mellem kognition og emotion i den menneskelige forståelse af verden.

Nærværende artikel er således et første, tentativt forsøg på at skabe en beskrivelse af humor, som anerkender og belyser dette samspil, og kræver derfor en tilsidesættelse af traditionelle faggrænser - som aldrig har været ment som en hæmsko, men snarere som en motivation for udforskningen af vores menneskelige virkelighed. Dette forsøg må imidlertid forblive en skitse, idet vi 
på nuværende tidspunkt mangler central viden, som er nødvendig for at formulere en formfuldendt teori. Disse dele tæller ikke blot samspillet mellem kognition og emotion - som også inden for den naturvidenskabelige hjerneforskning i længere tid har været kørt ud på et sidespor i forskningen (LeDoux 1999, Damasio 1994) - men også vores viden om forholdet mellem sprog og emotionelle reaktioner ${ }^{37}$, mellem humor og det øvrige følelsesrepertoire, og om humors biologiske fundament (selvom Gervais \& Wilson (2005) er en begyndelse), etc. Vi kan kun krydse fingre for, at fremtiden vil udbedre disse forhold.

Selvom ovenstående skitse af humorens væsen derfor langtfra er komplet, håber jeg, om ikke andet, at have vist med al tydelighed, hvorfor Piet Heins intuitive erkendelse af, at humor og spøg bør tages alvorligt og faktisk kan lære os noget om forhold, som har den største betydning for vores forståelse af os selv, vitterlig er udtryk for en vigtig erkendelse - og ikke blot er en ubetydelig leg med ord.

\section{KILDER}

Carstensen, Povl Erik (1996), Etvoerelses med spisetoilet. En stand-up encyklopoedi, København: Aschehoug.

Hartmann, Thomas (2006), Hartmann 3, Universal Music, DVD.

Kumbel Kumbell (pseudonym for Piet Hein) (1940), “Pædagogisk Gruk til Mogens Lorentzen", i: Kumbel Kumbell (1940): Gruk, 1. samling, København: Politikens Forlag.

Madsen, Anders Lund (1997), Madsens ÆØØÅ, ny revideret udgave, København: Aschehoug.

Wisby, Jacob (1971), 560 Humørpiller, Gylling: Forlaget Mikro.

\section{LITTERATUR}

Ambrose, Anthony (1963), "The Age of Onset of Ambivalence in Early Infancy: Indications from the Study of Laughing", Journal of Child Psychology and Psychiatry, 4 (1963), pp. 167-181.

Aritoteles (2004), Poetikken, nyoversat fra oldgræsk, noter og indledning/efterskrift af Niels Henningsen, Helsingør: Det Lille Forlag.

Attardo, Salvatore (1994), Linguistics Theories of Humor, Berlin: Mouton de Gruyter.

Bateson, Gregory (1969), "The Position of Humor in Human Communication", i: Levine, J. (red.), Motivation in Humor, New York: Atherton, pp. 159-166. 
Bechara, Antoine, Hanna Damasio, Antonio R. Damasio, Gregory P. Lee (1999), "Different Contributions of the Human Amygdala and Ventromedial Prefrontal Cortex to Decision-making", Journal of Neuroscience, 19 (1999), pp. 5473-5481.

Beeman, Mark Jung, Christine Chiarello (1998), "Complementary Right- and Left-hemisphere Language Comprehension", Current Directions in Psychological Science, 7/1, (1998), pp. 2-8.

Beeman, Mark Jung, Rhonda B. Friedman, Jordan Grafman, Enrique Perez, Sherri Diamond, Miriam B. Lindsay (1994), "Summation Priming and Coarse Coding in the Right Hemisphere", Journal of Cognitive Neuroscience, 6 (1994), pp. 26-45.

Bihrle, Amy M., Hiram H. Brownell, Howard Gardner (1986), “Comprehension of Humorous and Nonhumorous Materials by Left- and Rightbrain Damaged Patients", Brain and Cognition, 5/4, (1986), pp. 399-411.

Brownell, Hiram H., D. Michel, J. Powelson, Howard Gardner (1983), “Surprise But not Coherence: Sensitivity to Verbal Humor in Right-hemisphere Patients", Brain \& Language, 18/1, (1983), pp. 20-27.

Bræstrup, Frits Wimppfen (1952), Hjortebogen, København: Hans Reitzels Forlag.

Carr, Laurie, Marco Iacoboni, Marie-Charlotte Dubeau, John C. Mazziotta, Gian Luigi Lenzi (2003), "Neural Mechanisms of Empathy in Humans: A Relay from Neural Systems of Imitation to Limbic Areas", Proceedings of the National Academy of Sciences, USA, 100 (2003), pp. 5497-5502.

Coulson, Seana (2000), Semantic Leaps: Frame-shifting and Conceptual Blending in Meaning Construction, Cambridge \& New York: Cambridge University Press.

Coulson, Seana, Marta Kutas (2001), "Getting it: Human Event-related Brain Response to Joke in Good and Poor Comprehenders", Neuroscience Letters, 316 (2001), pp. 71-74.

Coulson, Seana, Christopher Lovett (2004), "Handedness, Hemispheric Asymmetries and Joke Comprehension", Cognitive Brain Research, 19 (2004), pp. 275-288.

Coulson, Seana, Robert F. Williams (2005), "Hemispheric Asymmetry and Joke Comprehension", Neuropsychologia, 43 (2005), pp. 128-141.

Damasio, Antonio (1994), Descartes' Error. Emotion, Reason and the Human Brain, New York: G. P. Putnam's Sons.

Damasio, Antonio (1999), The Feeling of What Happens: Body and Emotion in the Making of Consciousness, New York: Harcourt Brace \& Co.

Damasio, Antonio (2003), Looking for Spinoza: Joy, Sorrow, and the Feeling Brain, London: William Heineman.

Etkin, Amit, Tobias Egner, Daniel M. Peraza, Eric R. Kandel, Joy Hirsch (2006), "Resolving Emotional Conflict: A Role for the Rostral Anterior Cingulate Cortex in Modulating Activity in the Amygdala", Neuron, 51 (2006), pp. 1-12.

Eysenck, Hans Jürgen (1942), “The Appreciation of Humor: An Experimental and Theoretical Study", British Journal of Psychology, 32 (1942), pp. 295-209. 
Freud, Sigmund (1905), Der Witz und seine Beziehung zum Unbewussten, Leipzig/Wien: Deuticke.

Fry, William F. (2002), "Humor and the Brain: A Selective Review", Humor, 15/3, (2002), pp. 305-333.

Gervais, Matthew, David Sloan Wilson (2005), "The Evolution and Functions of Laughter and Humor: A Synthetic Approach", The Quarterly Review of Biology, 80/4, (2005), pp. 395-430.

Giora, Rachel (2003), On Our Mind: Salience, Context, and Figurative Language, Oxford: Oxford University Press.

Giora, Rachel (1997), "Understanding Figurative and Literal Language: The Graded Salience Hypothesis", Cognitive Linguistics, 7 (1997), pp. 183-206.

Gruner, Charles R. (1978), Understanding Laughter: The Workings of Wit and Humor, Chicago: Nelson-Hall.

Gruner, Charles R. (1997), The Game of Humor: A Comprehensive Theory of Why We Laugh, New Brunswick, NJ: Transaction.

Guthrie, William Norman (1903), "A Theory of the Comic", International Quarterly, 7 (1903), pp. 254-264.

Kant, Immanuel (1790/2005), Kritik af dømmekraften, oversættelse, noter og indledning ved Claus Bratt Østergaard, Helsingør: Det Lille Forlag.

Keith-Spiegel, Patricia (1972), "Early Conceptions of Humor: Varieties and Issues", i: Goldstein, J. H., P. E. McGhee (red.), The Psychology of Humor: Theoretical Perspectives and Empirical Issues, New York: Academic Press, pp. 339.

Koestler, Arthur (1964), The Act of Creation, London: Hutchinson.

Kutas, Marta, Kara D. Federmeier, Seana Coulson, Jonathan W. King, Thomas F. Münte (2000), "Language", i: Cacioppo, John T. et al. (red.), Handbook of Psychophysiology, 2. udgave, Cambridge: Cambridge University Press, p. 1039.

Kutas, Marta, Steven A. Hillyard (1980), "Reading Between the Lines: Eventrelated Brain Potentials During Natural Sentence Processing", Brain and Language, 11 (1980), pp. 354-373.

LeDoux, Joseph (1999), The Emotional Brain, New York: Phoenix.

McGhee, Paul E. (1971), "The Development of the Humor Response: A Review of the Literature", Psychological Bulletin, 76 (1971), pp. 328-348.

McGhee, Paul E. (1979), Humor: Its origin and development, San Francisco: Freeman.

MacHovec, Frank J. (1988), Humor: Theory, History, Applications, Springfield, IL: Charles C. Thomas.

Maier, Norman R. F. (1932), "A Gestalt Theory of Humor", British Journal of Psychology, 23 (1932), pp. 69-74.

Martin, Rod A. (1998), "Approaches to the Sense of Humor: A Historical Review", i: Ruch, Willibald (red.), The Sense of Humor. Explorations of a Personality Characteristic, Berlin: Mouton de Grutyer, pp. 15-60. 
Martin, Rod A. (2007), The Psychology of Humor. An Integrative Approach, Amsterdam: Elsevier Academic Press.

Monro, David Hector (1963), Argument of Laughter, Notre Dame, IN: University of Notre Dame Press.

Morreall, John (1987), The Philosophy of Laughter and Humor, New York: SUNY Press.

Nerhardt, Göran (1970), "Humor and Inclination to Laugh: Emotional Reactions to Stimuli of Different Divergence from a Range of Expectancy", Scandinavian Journal of Psychology, (1970), pp. 185-195.

Nerhardt, Göran (1976), "Incongruity and Funniness: Towards a New Descriptive Model", i: Chapman, A. J., H. C. Foot (red.), Humor and Laughter: Theory, Research, and Applications, 11/3, London: John Wiley \& Sons, pp. 5562.

Nieuwenhuys, Rudolf (1985), Chemoarchitecture of the Brain, Berlin: Springer.

Nieuwenhuys, Rudolf (1996), "The Greater Limbic System, the Emotional Motor System and the Brain", Progress in Brain Research, 107 (1996), pp. 551-580.

Nieuwenhuys, Rudolf, Hans J. Ten Donkelaar, Charles Nicholson (1998), The Central Nervous System of Vertebrates, Berlin: Springer.

Nieuwenhuys, Rudolf, Jan Voogd, Chris Van Huijzen (2007), The Human Central Nervous System. A synopsis and Atlas, 4. reviderede udgave, Berlin: Springer.

Piddington, Ralph (1963), "The Psychology of Laughter: A Study in Social Adaptation", New York: Garmut Press.

Platon (1859), Philebos, oversat af C. J. Heise, København: Reitzels Forlag.

Provine, Robert R. (2000), Laughter: A Scientific Investigation, New York: Viking.

Ramachandran, Vilayanur S. (1998), "The Neurology and Evolution of Humor, Laughter, and Smiling: The False Alarm Theory", Medical Hypotheses, 51 (1998), pp. 351-354.

Raskin, Victor (1985), Semantic Mechanisms of Humor, Dordrecht: D. Reidel.

Rothbart, Mary K. (1976), "Incongruity, Problem-solving and Laughter", i: Chapman, Anthony J., Hugn C. Foot (red.), Humor and Laughter: Theory, Research, and Applications, London: John Wiley \& Sons, pp. 37-54.

Ruch, Willibald (1997), "State and Trait Cheerfulness and the Induction of Exhilaration: A FACS-study", European Psychologist, 2 (1997), pp. 328-341.

Ruch, Willibald, Gabriele Köhler (1998), "A Temperament Approach to Humor", i: Ruch, Willibald (red.), The Sense of Humor. Explorations of a Personality Characteristic, Berlin: Mouton de Grutyer, pp. 203-228.

Scheerer, Martin (1948), "An Aspect of the Psychology of Humor", præsenteret for Graduate Faculty of the New School for Social Research, New York, 19. maj 1948, publiceret i: Bulletin of the Menninger Clinic, 30 (1966), pp. 86-97.

Schopenhauer, Arthur (1818/2006), Verden som vilje og forestilling, oversættelse, indledning og noter ved Søren R. Fauth, København: Gyldendal. 
Shammi, Prathiba, Donald T. Stuss (1999), "Humor Appreciation: A Role of the Right Frontal Lobe", Brain, 122 (1999), pp. 657-666.

Spencer, Herbert (1860), "The Physiology of Laughter", Macmillan's Magazine, 1 (1860), pp. 395-402.

Suls, Jerry M. (1972), "A Two-stage Model for the Appreciation of Jokes and Cartoons: An Information-processing Analysis", i: Goldstein, J. H., P. E. McGhee (red.), The Psychology of Humor: Theoretical Perspectives and Empirical Issues, New York: Academic Press, pp. 3-39.

Svebak, Sven (2000), Forlenger en god latter livet? Humor, stress og helse, Bergen: Fagbokforlaget.

Watson, Karli K., Benjamin J. Matthews, John Morgan Allman (2007), "Brain Activation during Sight Gags and Language-dependent Humor", Cerebral Cortex, 7/2, (2007), pp. 314-24.

Wimsatt, William K. (1954), The Verbal Icon: Studies in the Meaning of Poetry, Kentucky: University of Kentucky Press.

\section{NOTER}

1 At inddrage den emotionelle reaktion i en sproglig/litterær analyse er langtfra uproblematisk. Der er dels en udbredt mangel på metode, hvorved dette kan gøres, og dels har der inden for de fleste fag været en traditionel modvilje mod at inddrage emotionelle reaktioner $i$ analysen af sproglige udsagn, til fordel for en mere logisk eller stringent systematisk analyse. De to ting hænger naturligvis sammen, idet manglen på metode i høj grad udspringer af modviljen mod at beskæftige sig med det emotionelle aspekt af sprog og litteratur. Inden for mit eget fag, litteraturvidenskaben, opstod denne modvilje som en reaktion på romantikkens fokus på værkers æstetiske værdi og blev opsummeret i Wimsatt \& Beardsleys (1954) indflydelsesrige essay om The Affective Fallacy. Denne "affektive fejltagelse" består i at forveksle digtet med dets resultat ("what it is and what it does" - Wimsatt 1954: 21), og det vigtigste argument herfor, var en opfattelse af, at værkets kognitive struktur er almen og generel, mens den emotionelle reaktion, som den udvirker, er individuel. Når vi taler om humor, er der imidlertid tale om en (forholdsvis) forudsigelig emotionel reaktion - som endda kommer til udtryk på en universel og observérbar måde: latter - hvorimod de kognitive mekanismer, som udløser den, kan variere (endda meget) fra situation til situation.

2 Andre historiske overblik over humorforskning er f.eks. MacHovec (1998), Monro \& Piddington (1963), Martin (2007), og Morreal (1987) - som jeg naturligvis står i gæld til for historiske referencer omkring humorteorier før og nu.

3 "To present a summary of the nature of humor by drawing together all of the scattered pieces rent apart over centuries of theorizing would be, to put it mildly, an impossibility" (Keith-Spiegel 1972: 34).

4 Årsagen til at disse aggressionsteorier om humor alligevel har været historisk fremtrædende, kan være, at der i virkeligheden er to forskellige former for latter, Duchenne og ikke-Duchenne (Gervais \& Wilson 2005), som styres af forskellige centre i hjernen, udløses i forskellige situationer, og hvoraf kun 
sidstnævnte i nogen grad kan siges at være associeret med social aggression. Gervais \& Wilson påpeger desuden, at ikke-Duchenne-latter sandsynligvis er opstået efter Duchenne-latter i udviklingshistorien, som en efterudvikling af denne, hvorfor sidstnævnte ikke kan bruges som udgangspunkt for en beskrivelse af humors oprindelse. I resten af denne artikel vil vi derfor koncentrere os om den form for humor, som er associeret med Duchennelatter.

5 Suls (1972) beskriver flere forskellige grunde til, at vittigheder kan være sjove, selv anden gang. De er, kort fortalt: 1) vittigheder, som ikke er meget sjove, huskes ikke så godt (da de mest intense oplevelser huskes bedst), og derfor kan man glemme pointen, 2) der kan være flere grunde til, at en vittighed er sjov - og dermed flere overraskelser, 3) vittigheden er blevet forbundet med den positive tilstand første gang, man hørte den, og 4) vittigheden kan blive endog endnu sjovere, når den er befriet for den utryghed, som er forbundet med at opleve noget nyt og ukendt (Suls 1972: 94).

6 Når lagkage-eksemplet og banan-eksemplet kan slippe af sted med at være så forudsigelige, skyldes det sandsynligvis, at humor her ikke kun udløses af overraskelsen, men også af en identifikation med den person, som det går ud over - se senere under beskrivelsen af falde-på-halen komik.

7 De har dog begge bidraget med væsentligt mere til forståelsen af humor end som så - se senere.

8 Suls (1972) nævner selv både Maier (1932), som talte om en "omstrukturering" (restructuring), som fandt sted efter inkongruensen, og Bateson (1969) som sine foregangsmænd.

9 Forklaringen herpå er nok den simple, at inkongruensens bidrag til oplevelsen af humor netop ikke er forbundet med behag - men med ubehag. For en nærmere forklaring, se senere i nærværende artikel.

10 Andet led i Suls' model bliver ofte kaldt "opløsning" (resolution) (Shammi \& Stuss 1999) eller "sammenhæng" (coherence) (Coulson \& Kutas 2001), mens Suls selv udelukkende benytter betegnelsen "problemløsning" (problemsolving) - og evt. genskabelse af kongruens - i sin originale artikel (1972). Den omfortolkning af forståelsesrammen, som er nødvendig for at læsningen giver mening i et nyt lys, bliver af forskellige teoretikere også beskrevet på forskellig vis, ved hjælp af forskellige teoretiske begreber, som f.eks. schemas, scripts (Raskin 1985, Attardo 1994, Giora 2003) eller frames (Coulson \& Kutas 2001). Det er imidlertid ikke min hensigt at beskæftige mig med de finere detaljer i forskellene mellem disse begreber i denne artikel.

11 Vittigheden er her gengivet med den (korrekte) morsomme pointe. De alternative slutninger lød i dette tilfælde:

[SF] Straightforward: The man says, "Can you spare a little change for a blind man?"

[ANS] Associative non-sequitur: The man says, "My seeing eye dog is 10 years old."

[NNS] Neutral non-sequitur: The man says, "I really enjoy going to the symphony."

[HNS] Humorous nonsequitur: Then the blind man throws a pie in the woman's face. 
12 Disse karakteristika ser Beeman som et direkte resultat af de to hjernehalvdeles forskelligartede anatomi, hvor højre er præget af flere og mere forgrenede forbindelser, som tænkes at udgøre et mere komplekst netværk end i venstre hjernehalvdel (Beeman \& Chiarello 1998, Coulson \& Williams 2005). Der er samtidig flere forbindelser mellem hjernebarken i venstre hjernehalvdel og basalganglierne (putamen og nucleus caudatus), der beskrives som involveret i handlesekvenser, i forhold til højre, som er tættere forbundet til hjernens emotionelle netværk.

13 I Coulsons optik fortolkes dette N400-potentiale endvidere som et korrelat for et skift af fortolkningsramme i læsningen, som svarer til hendes teoretiske grundbegreb frame-shifting (Coulson 2000).

14 "While the positivities have been argued to reflect a surprise component of joke processing, and the sustained negativity to index frame-shifting needed to re-establish coherence, all three effects occur within the same time window." (Coulson \& Kutas 2001: 71).

15 Hvilket muligvis er årsagen til at Seana Coulson i sine efterfølgende forsøg, f.eks. Coulson \& Lovett (2004) og Coulson \& Williams (2005), i stedet har koncentreret sig om de to hjernehalvdeles bidrag til opfattelsen af humor.

16 Det er i denne sammenhæng muligt at se Bateson (1969) - som Suls nævner som sin foregangsmand - som en forløber for Gioras opfattelse af humor, idet han - med Suls' ord (1972: 95) - "suggested that humor occurs when the punch line brings what was background material for a joke suddenly and unexpectedly to the center of attention, as in the reversal of figure and ground."

17 "In sum, while jokes and other tropes (irony, metaphor) share similar early processes activating salient meanings initially, they diverge with regard to integration processes. Whereas understanding irony and metaphor involves retention of salient, though contextually incompatible meanings [...], joke interpretation does not." (Giora 2003: 175).

18 Se f.eks. også Keith-Spiegel (1972: 31).

19 Som også Wimsatt \& Beardsley (1954) er eksponent for.

20 [§54] "Das Lachen ist ein Affekt aus der plötzlichen Verwandlung einer gespannten Erwartung in nichts."

21 "To lead our 'one-track mind' down 'the garden path', the initial content of a joke is usually unambiguous, compatible with the salient meaning, so that this interpretation is retained up until the punch line, at which point a sudden incongruity forces reinterpretation." (Giora 2003: 168)

22 Coulson og kollegers påvisning af, at N400-potentialet - som de har døbt the N400 joke effect - er større ved vittigheder, hvor pointen erstatter en entydigt forudsigelig slutning (high constraint- eller high cloze-sætninger), end i vittigheder, hvor der ikke er nogen på forhånd givet entydig afslutning (low constraint- eller low cloze-sætninger), som pointen træder i stedet for, peger også i retning af, at vittighedens forløb - op til pointen - snarere er præget af forudsigelighed end spænding (Coulson \& Kutas 2001, Coulson \& Lovett 2004, Coulson \& Williams 2005).

23 Man kan naturligvis forsøge at argumentere for, at det er selve den humoristiske ramme, som leverer den spænding eller forventning, som 
udløses i pointen. Oftest vil man på forhånd vide, at der er tale om en vittighed - det siges måske direkte ("har du hørt den om ..."), eller også befinder man sig i en situation, hvor humor forventes (man er taget ind for at se revy, stand-up, komedie el.lign.). Men det kan næppe betragtes som en dækkende beskrivelse af humorens væsen (særligt ikke i forhold til sproglig humor), da den jo overser det essentielle element i langt de fleste nyere teorier om humor, nemlig inkongruens, som jo netop anses for at skabe den spænding, som bevirker, at vi finder vittigheden sjov - og dermed også den spænding eller psykiske energi, som ifølge modellen skal udløses i humor.

24 Nemlig den såkaldte ikke-Duchenne-latter, se Gervais \& Wilson (2005: 400).

25 "Humor scientists are well aware that humor does not fit into a pleasant/unpleasant scheme. Humorous/serious is a different axis from the pleasant/unpleasant axis." (Fry 2002: 326)

26 Ambivalens var tidligere et vigtig element i forsøget på at forstå humor, f.eks. hos Ambrose (1963), som så den som den måske vigtigste udløsende faktor for humor, men er i vidt omfang gledet ud i senere tiders teorier (Fry 2002).

27 Det er naturligvis muligt - og endda forholdsvis let - at argumentere for at den fysiske komik skal ses som et udslag af den nedladende, udstødende, selvhævdende humor, hvor vi primært griner af andres ulykke. Men det passer bare dårligt med, at vi typisk fatter sympati for aktørerne i denne humor, f.eks. klovnen. Spørgsmålet er, om ikke identifikationen med aktøren reelt er nødvendig, for at vi overhovedet reagerer på den fysiske humor? En identifikation, som, på baggrund af de senere års påvisning af de såkaldte "spejlneuroner" (mirror neurons), som er aktive både under udførelse af en bevægelse, og under iagttagelse af andre, der udfører samme bevægelse (og som dermed kan forklare, hvordan vi kan "føle med" folk, som udfører en fysisk handling eller falder, etc.), endda kan beskrives i detaljer (Carr et al. 2003).

28 Dette eksempel er interessant, da beskrivelsen er direkte kopieret fra Adams \& Lloyds bog, hvor den optræder som shoeburyness. Man kan derfor tillade sig at antage, at netop denne type situationsbeskrivelse har været en del af Anders Lund Madsens egen fascination af Adams \& Lloyds bog (og dermed motivationen for at skrive sin egen), idet han har gengivet den i sin egen udgave.

29 At den beskrevne inkongruens - paradokset - både (som Schopenhauer understreger) kan opstå ved ord og handling, er blevet bekræftet af en række forsøg udført af Göran Nerhardt (1970, 1976). Forsøgspersonerne blev bedt om at vurdere vægten af en række genstande, som de bagefter blev bedt om at løfte. De genstande (vægte), som afveg meget fra forventningerne, udløste en humoristisk respons (som dog var størst når de var tungere end forventet). Nerhardt mente hermed at have understøttet sin opfattelse af, at inkongruensen mellem forventning og virkelighed er nok til at udløse humor. Han fandt samtidig ud af, at det var en forudsætning for, at dette forsøg - som var camoufleret som et psykologisk forsøg - udløste humor, at det blev udført i en afslappet, løssluppen ramme (se også Martin 2007).

30 Denne opfattelse stemmer udmærket overens med den neuroanatomiske beskrivelse af hjernens emotionelle netværk. Den traditionelle opfattelse af vores følelsesmæssige oplevelser som styret af et limbisk system, der er beskrevet som en funktionel og arkitektonisk enhed, har i de senere år været 
under beskydning fra funktionelt fokuserede forskere, som f.eks. Joseph LeDoux (1999). I den neuroanatomiske forskning har man imidlertid i de seneste årtier identificeret et forstørret limbisk system (greater limbic system), som strækker sig fra centre bagest i hjernestammen og frem mod de traditionelle limbiske centre, som forbinder krop og hjerne og dermed muliggør, at repræsentationen af kroppens indre tilstand bliver koblet med de subkortikalt-styrede overlevelsesinstinkter og med den kortikalt-styrede kognitive tænkning. Dette systems karakteristika er (udover den cytoarkitektoniske enhed) tilstedeværelsen af en rig cocktail af neuromediatorer og neurotransmitterstoffer, som typisk spredes i det ekstracellulære rum ved diffus spredning (volume transmission), snarere end diskret celle-til-celle kommunikation som ved traditionel synapse-aktivitet (som det typisk sker i hjernebarken), og dets grundlæggende funktion er dermed skabelse af globale tilstande, snarere end videregivelse af diskret information (Nieuwenhuys 1985, Nieuwenhuys 1996, Nieuwenhuys et al. 1998, Nieuwenhuys et al. 2007). Dets kortikale repræsentation foregår primært i områder som insula eller gyrus cingularis anterior - hvilket, som vi skal se om lidt, ikke er uden betydning for oplevelsen af humor.

31 Guthrie mente dog samtidig, at mens smil var medfødt, var latter tillært hvilket ikke er korrekt (Keith-Spiegel 1972).

32 Denne omfortolkning sættes bemærkelsesværdigt nok i relation til Antonio Damasios begreb om "somatiske markører" (somatic markers), idet der henvises til et studie af bl.a. Damasio og Antonio Bechara (Bechara et al. 1999). Begrebet "somatiske markører" dækker over en forestilling om, at der i de dele af hjernen, som er involveret i den stadige overvågning af kroppens indre tilstand, skabes en repræsentation af sammenhængen mellem de ydre stimuli og den indre tilstand, som er koblet til disse. Disse markører har den fordel, at de kan aktiveres langt hurtigere, end kroppens normale fysiologiske reaktioner og dermed skabe en emotionel respons på en ydre påvirkning inden for en meget kort tidsramme - hvilket blandt andet er påkrævet i humor. Det bemærkelsesværdige er, at netop amygdala her fremhæves, idet Damasio primært har sat fokus på områder i og omkring insula og gyrus cingularis anterior, som de væsentligste placeringer for hjernens repræsentation af kroppens indre tilstande (Damasio 1994, 1999, 2003).

33 Hvilket er en af årsagerne til amygdalas korte reaktionstid, idet det er af biologisk fordel at kunne reagere hurtigt på eventuelle farer - sml. humors overraskelseselement.

34 Dette studie blev udført med en særlig opgave (emotional Stroop task), som netop tog udgangspunkt i en konflikt, som blev skabt ved hjælp af en inkongruens mellem ord og billede (et ansigtsudtryk). Udløsningen af aktivitet i amygdala skete således på en måde, som ikke ligger langt fra det, vi må forestille os må foregå i humor.

35 Sml. Etkins et al. (2006: 8): "Taken together, these studies suggest that the response to threat in healthy subjects involves two distinct stages - an initial unconscious, anxiety-related bias reflected in amygdala activation (and with it enhanced vigilance), followed by a secondary context-responsive suppression of amygdalar responsiveness by the rostral cingulate."

36 Humor er dermed knyttet til et biologisk behov for at søge viden om netop de emner, som kan være en potentiel trussel for os - hvilket passer som fod i hose med, at de ting, som er forbundet med en emotionel ophidselse 
THOMAS RAAB

(arousal), huskes bedre, fordi det er et signal om, at de har en biologisk betydning for os.

37 - som er af begrænset omfang, og som her ikke er medtaget af hensyn til klarhed og omfang af denne artikel. 